\title{
The Management and Operation of Presently Registered Milk Tea Store in Cabanatuan City
}

\author{
Joy N. Savellano
}

College of Management and Business Technology, Nueva Ecija University of Science and Technology, Cabanatuan City, Philippines

Received: 11 Jan 2021; Received in revised form: 03 Mar 2021; Accepted: 29 Mar 2021; Available online: 28 Apr 2021 (C)2021 The Author(s). Published by The Shillonga Publication. This is an open access article under the CC BY license (https://creativecommons.org/licenses/by/4.0/).

\begin{abstract}
Milk Tea Industry has evolved rapidly compared to the other business industry. This study was undertaken to know the profile of the milk tea store, the management and operation, the SWOT analysis, and the problems encountered by the Milk Tea store in Cabanatuan City. Ten (10) Milk Tea stores around Cabanatuan City were included in the study. Various techniques for data gathering were used like informal interviews, observation and questionnaires. The researcher discovered that most of the Milk Tea store operated ranging from one to five years and majority of them has three maximum numbers of branches with an initial capital of not more than one hundred thousand. Most of the respondents have earned average weekly sales of not more than twenty thousand pesos. Each Milk Tea store has different numbers of employees. They met and always maintained the management quality standards of the organization's operation. Few of them used direct advertising and discount promo as a tool in promoting their business. The taste of their products is what attracted the customers most. Results of the study also showed the continuous effort of the owners in making strategies that can help and improve their business like making the image of their products more appealing and healthier to their customers. Current challenges faced by the respondents are: there was a fast entry of competitors; the scandal issue directly affected the business as well the behavior of the consumers. But in spite of that, management of different Milk Tea Stores always remain positive, confident and ready to device ways on resolving problems.
\end{abstract}

Keywords-Milk Tea Store; quality standard; SWOT analysis; image of the product; consumer behavior; effects of the milk tea scandal issue.

\section{INTRODUCTION}

Milk Tea Store is one of the most popular businesses now days. Milk tea shops became prevalent, not just in upper- and middle-class professionals, but also to high school, college students and even to individuals who simple looks for a good ambiance, a cool place to hang around while enjoying a sip of their favorite milk tea product. People are patronizing this product mainly because it brings different kind of sensation causing them to feel refresh and relax aside from it really satisfies their taste buds.

Today, Milk Tea Store is considered as a viable business because of continuous increase in demand as well as it is easy to set up. A milk tea product was formerly called pearl tea, but also commonly referred to as bubble tea or boba tea in different countries. The name was taken from the fact that it originated as a drink made out of a combination of chilled tea with milk, a sweeter (traditional sugar), and rehydrated tapioca pearls for chewiness. The term does not cover a wide range of other products commonly seen and served by vendors on the street, like "sago at gulaman." These products may refresh the thirst of some buyers, but definitely, milk tea products, from its total packaging, to its preparation and place/location where it could be bought, spells a lot of difference.

But just like any other businesses, Milk Tea Stores also encountered challenges and problems, like what happened on the 2015 Sampaloc, Manila Milk Tea Poisoning that resulted to a tragic event where two people died. The said incident affected the Milk Tea Industry as well as the behavior of consumers who patronizes milk tea products. The currently registered ten Milk Tea Stores here in Cabanatuan City have experienced the negative implications of that event, as to what and in what ways, as well as the strategies how they handle such kind of 
problem and other things, are the prime concern of this study.

\section{OBJECTIVES OF THE STUDY}

This research study focused on the management and operation of 10 presently registered Milk Tea Store in Cabanatuan City. Specifically, it seeks to determine the following:

1. To describe the profile of 10 presently registered milk tea stores in terms of the following;

1.1 Number of years of operation;

1.2 Average weekly sales;

1.3 Number of branches;

1.4 Initial capital; and

1.5 Number of employees

2. To describe the management strategies of registered milk tea stores in terms of;

2.1 Qualities of products;

2.2 Pricing; and

2.3 Advertising and promotion

3. To identify the current condition of the milk tea businesses in terms of its;

3.1 Strengths;

3.2 Weaknesses;

3.3 Opportunities; and

3.4 Threats

4. To describe the effects of harm done as experienced by the registered milk tea stores in Cabanatuan City caused by the 2015 Sampaloc, Manila Milk Tea Poisoning

5. To describe different strategies practice and performed by registered milk tea stores in Cabanatuan City in handling various challenges or problems in their operations

\section{METHODOLOGY}

Descriptive method was used by the researcher in gathering information such as informal interviews, observation and questionnaires in the 10 presently registered Milk Tea Stores in Cabanatuan City.

The statistical treatment used was the simple frequency, percentage, average weighted means and ranking. Those procedures were performed to compute and evaluate the result of the survey in terms of the Milk Tea Stores' management and operation particularly in the areas of quality standard, pricing, advertising and promotion, including its current SWOT analysis and problems met.

\section{FINDINGS}

1. Profile Description of the Presently Registered Milk Tea Stores in Cabanatuan City in terms of:

Table I: Number of Years in Operation

\begin{tabular}{|c|c|c|}
\hline $\begin{array}{c}\text { Number of Years } \\
\text { Frequency }\end{array}$ & $\begin{array}{c}\text { Percentag } \\
e\end{array}$ \\
\hline $1-5$ & 8 & $80 \%$ \\
\hline $6-10$ & 2 & $20 \%$ \\
\hline $11-15$ & - & - \\
\hline Total & $\mathbf{1 0}$ & $\mathbf{1 0 0 \%}$ \\
\hline
\end{tabular}

Most of the respondents of Milk Tea Stores here in Cabanatuan City are just newly established and were operating between 1 to 5 years.

Table II: Average Weekly Sales

\begin{tabular}{|c|c|c|}
\hline Weekly Sales & Frequency & Percentages \\
\hline P $1000-5,000$ & 1 & $10 \%$ \\
\hline $6,000-10,000$ & 2 & $20 \%$ \\
\hline $11,000-15,000$ & 2 & $20 \%$ \\
\hline $16,000-20,000$ & 5 & $50 \%$ \\
\hline Total & $\mathbf{1 0}$ & $\mathbf{1 0 0 \%}$ \\
\hline
\end{tabular}

It could be seen that majority of milk tea store in Cabanatuan City are earning profit that can sustain the daily operation of the business.

Table III: Number of Branches in Cabanatuan City

\begin{tabular}{|c|c|c|}
\hline Number of Branches & $\begin{array}{c}\text { Frequenc } \\
y\end{array}$ & $\begin{array}{c}\text { Percentag } \\
e\end{array}$ \\
\hline 0 & 1 & $10 \%$ \\
\hline 1 & 1 & $10 \%$ \\
\hline 2 & 3 & $30 \%$ \\
\hline 3 & 5 & $50 \%$ \\
\hline Total & $\mathbf{1 0}$ & $\mathbf{1 0 0 \%}$ \\
\hline
\end{tabular}

Based on the information gathered, it could be interpreted that $80 \%$ of the owners' of presently registered milk tea business has branches that is three and above, an indication that this business is really viable and in demand. 
Table IV: Initial Capital

\begin{tabular}{|c|c|c|}
\hline Initial Capital & Frequency & Percentages \\
\hline P 20,000- 30,000 & 1 & $10 \%$ \\
\hline P 30,001- 50,000 & 1 & $10 \%$ \\
\hline P 50,001- 70,000 & - & - \\
\hline $\begin{array}{c}\text { P 70,001- } \\
100,000\end{array}$ & 8 & $80 \%$ \\
\hline Total & $\mathbf{1 0}$ & $\mathbf{1 0 0 \%}$ \\
\hline
\end{tabular}

Majority of the respondents started their business operation with an initial capital between seventy-thousand pesos to one-hundred thousand pesos only. This shows that this kind of business is easy to put up considering the reasonable start-up capital requirement.

Table V: Number of Employees throughout Cabanatuan City

\begin{tabular}{|c|c|c|}
\hline Number of Employees & $\begin{array}{c}\text { Frequenc } \\
y\end{array}$ & $\begin{array}{c}\text { Percentage } \\
s\end{array}$ \\
\hline $1-3$ & 4 & $40 \%$ \\
\hline $4-6$ & 5 & $50 \%$ \\
\hline $7-9$ & 1 & $10 \%$ \\
\hline 10 above & - & - \\
\hline Total & $\mathbf{1 0}$ & $\mathbf{1 0 0 \%}$ \\
\hline
\end{tabular}

Four to six employees are mostly the number of employees this kind of business have. Running this kind of business requires only a minimal number of employees, since it involves only simple, yet standardized operation of servicing refreshment or meal to customers.

2. Management strategies of milk tea stores in Cabanatuan City in terms of:

Table VI: Quality of the Products/Services

\begin{tabular}{|l|c|c|}
\hline \multicolumn{1}{|c|}{ Item Statement } & $\begin{array}{c}\text { Weighted } \\
\text { Mean } \\
(W M)\end{array}$ & $\begin{array}{c}\text { Descriptive } \\
\text { Value } \\
(D V)\end{array}$ \\
\hline $\begin{array}{l}\text { 1. Maintaining quality } \\
\text { standard of milk tea } \\
\text { services. }\end{array}$ & 5 & Always \\
\hline $\begin{array}{l}\text { 2. Handling breakable } \\
\text { /sensitive milk tea } \\
\text { commodities. }\end{array}$ & 4.6 & Always \\
\hline $\begin{array}{l}\text { 3. Assigning specific } \\
\text { job to every employee. }\end{array}$ & 4.6 & Always \\
\hline 4 .Disposing ingredient & 4.7 & Always \\
\hline
\end{tabular}

\begin{tabular}{|c|c|c|}
\hline Item Statement & $\begin{array}{c}\text { Weighted } \\
\text { Mean } \\
(W M)\end{array}$ & $\begin{array}{c}\text { Descriptive } \\
\text { Value } \\
(D V)\end{array}$ \\
\hline $\begin{array}{c}\text { of shorter expiry date. } \\
\text { Average weighted } \\
\text { mean } \\
(\mathbf{A W M})\end{array}$ & $\mathbf{4 . 7 4}$ & Always \\
\hline
\end{tabular}

The above information shows that the presently registered Milk Tea Businesses around Cabanatuan City always meets the management's quality standard set for the organization's operation in maintaining the quality of their products' taste and services.

Table VII: Pricing

\begin{tabular}{|c|c|c|}
\hline \multicolumn{1}{|c|}{ Item Statement } & $\begin{array}{c}\text { Weighted } \\
\text { Mean } \\
(W M)\end{array}$ & $\begin{array}{c}\text { Descriptive } \\
\text { Value } \\
(D V)\end{array}$ \\
\hline 1. Fixed pricing policy & 4.7 & Always \\
\hline $\begin{array}{l}\text { 2. Owned pricing } \\
\text { technique } \\
\text { Average weighted } \\
\text { mean (AMW) }\end{array}$ & 3.5 & Seldom \\
\hline
\end{tabular}

The above data shows that the milk tea store often use pricing strategy as their way to attract buyers but most of the Milk Tea Store used a fixed pricing scheme even if there is an stiff competition. In a fixed price system, the management sets already the prices of their products at an amount where they could get a desirable mark-up on it that cannot be subjected to bargaining.

Table VIII: Advertising and Promotion

\begin{tabular}{|l|c|c|}
\hline \multicolumn{1}{|c|}{ Item Statements } & $\begin{array}{c}\text { Weighted } \\
\text { Mean } \\
(W M)\end{array}$ & $\begin{array}{c}\text { Descriptive } \\
\text { Value } \\
(D V)\end{array}$ \\
\hline $\begin{array}{l}\text { 1. Radio and } \\
\text { Television }\end{array}$ & 1.5 & Never \\
\hline 2. Direct Advertising & 1.9 & Seldom \\
\hline 3. Social Media & 2.9 & Sometimes \\
\hline $\begin{array}{l}\text { 4. Discounts promo } \\
\text { 5. Leaflets }\end{array}$ & 2.3 & Seldom \\
\hline $\begin{array}{c}\text { Average weighted } \\
\text { mean (AWM) }\end{array}$ & $\mathbf{2 . 0 6}$ & Seldom \\
\hline
\end{tabular}


Milk Tea Businesses in Cabanatuan City seldom use advertising and some promotional tool in promoting their products and services, although, sometimes they use social media for it is the cheapest and convenient tool in promoting businesses at present.

3. Current condition of Milk Tea Businesses in terms of:

Table IX: Strengths

\begin{tabular}{|l|c|c|}
\hline \multicolumn{1}{|c|}{ Item Statements } & $\begin{array}{c}\text { Weighted } \\
\text { Mean } \\
(W M)\end{array}$ & $\begin{array}{c}\text { Descriptive } \\
\text { Value } \\
(D V)\end{array}$ \\
\hline $\begin{array}{l}\text { 1. The location of } \\
\text { the business is ideal. }\end{array}$ & 5 & $\begin{array}{c}\text { Strongly } \\
\text { Agree }\end{array}$ \\
\hline $\begin{array}{l}\text { 2. Have sufficient } \\
\text { income to support } \\
\text { the day to day } \\
\text { operation. }\end{array}$ & 4.8 & $\begin{array}{c}\text { Strongly } \\
\text { Agree }\end{array}$ \\
\hline $\begin{array}{l}\text { 3. Accessible to the } \\
\text { target market/ has a } \\
\text { strong customer } \\
\text { base. }\end{array}$ & 4.7 & $\begin{array}{c}\text { Strongly } \\
\text { Agree }\end{array}$ \\
\hline $\begin{array}{l}\text { 4. The deliciousness } \\
\text { and popularity of } \\
\text { the milk tea offered. } \\
\text { mean }\end{array}$ & 5 & Strongly \\
\hline $\begin{array}{l}\text { 5. The affordability } \\
\text { of the price. }\end{array}$ & 4.5 & Atrongly \\
\hline $\begin{array}{l}\text { Agree } \\
\text { well trained and } \\
\text { friendly. }\end{array}$ & 5.9 & $\begin{array}{c}\text { Strongly } \\
\text { established. }\end{array}$ \\
\hline $\begin{array}{l}\text { Average weighted } \\
\text { Agree }\end{array}$ \\
\hline
\end{tabular}

Milk Tea Businesses have a numerous strength which enable them to meet their organizations' objectives as well as meeting their customers' needs and expectations. The key why they were able to establish a very strong foundation of their strengths is caused by excellent planning that includes the most basic of all, and that is choosing the right location for the business, hiring the right person for the job and setting a standard products' taste that will mark as their brand.
Table X: Weaknesses

\begin{tabular}{|l|c|c|}
\hline \multicolumn{1}{|c|}{ Item Statements } & $\begin{array}{c}\text { Weighted } \\
\text { Mean } \\
(W M)\end{array}$ & $\begin{array}{c}\text { Descriptive } \\
\text { Value } \\
(D V)\end{array}$ \\
\hline $\begin{array}{l}\text { 1. Improving the } \\
\text { areas of the business } \\
\text { that is lacking. }\end{array}$ & 3.4 & Sometimes \\
\hline $\begin{array}{l}\text { 2. The location is far } \\
\text { from the target } \\
\text { market. }\end{array}$ & 2.2 & Rarely \\
\hline $\begin{array}{l}\text { 3. The employees } \\
\text { are not competitive. }\end{array}$ & 1.7 & Never \\
\hline $\begin{array}{l}\text { 4.The prices are not } \\
\text { affordable }\end{array}$ & 1.4 & Never \\
\hline $\begin{array}{l}\text { 5. Negligence in } \\
\text { processing the } \\
\text { product. }\end{array}$ & 2.1 & Rarely \\
\hline $\begin{array}{l}\text { 6. The customers } \\
\text { lose their loyalty. }\end{array}$ & 2.1 & Rarely \\
\hline $\begin{array}{l}\text { Average weighted } \\
\text { mean }\end{array}$ & $\mathbf{2 . 2 2}$ & \\
\hline
\end{tabular}

From the above listed item, never did the Milk Tea Businesses encountered problems on the performances of their employees as well as complaints from their customers on prices of their products. This situation indicates that they really choose well and trained their employees before assigning them to do the job. Customers' complaints on prices were avoided because of the fixed price system practiced mostly by Milk Tea Businesses that made the customers agreed on the given prices set by the management. Over all, rarely did this type of businesses encountered problems in dealing with their weaknesses.

Table XII: Opportunities

\begin{tabular}{|l|c|c|}
\hline \multicolumn{1}{|c|}{ Item Statements } & $\begin{array}{c}\text { Weighted } \\
\text { Mean } \\
(W M)\end{array}$ & $\begin{array}{c}\text { Descriptive } \\
\text { Value } \\
(D V)\end{array}$ \\
\hline $\begin{array}{l}\text { 1. The availability } \\
\text { and use of modern } \\
\text { technology and } \\
\text { equipment for the } \\
\text { betterment of } \\
\text { operation of the } \\
\text { business. }\end{array}$ & 4.7 & $\begin{array}{c}\text { Strongly } \\
\text { Agree }\end{array}$ \\
\hline $\begin{array}{l}\text { 2. Discovery of new } \\
\text { resources that could }\end{array}$ & 2.7 & Sometimes \\
\hline
\end{tabular}




\begin{tabular}{|c|c|c|}
\hline Item Statements & $\begin{array}{c}\text { Weighted } \\
\text { Mean } \\
(W M)\end{array}$ & $\begin{array}{c}\text { Descriptive } \\
\text { Value } \\
(D V)\end{array}$ \\
\hline $\begin{array}{l}\text { be used in } \\
\text { developing new } \\
\text { product offerings. }\end{array}$ & & \\
\hline $\begin{array}{l}\text { 3. Potential increase } \\
\text { in market share and } \\
\text { customers. }\end{array}$ & 4.3 & $\begin{array}{c}\text { Strongly } \\
\text { Agree }\end{array}$ \\
\hline $\begin{array}{l}\text { 4. Accessibility to } \\
\text { different utilities like } \\
\text { cable signal, internet } \\
\text { connection, \& others. }\end{array}$ & 4.8 & $\begin{array}{c}\text { Strongly } \\
\text { Agree }\end{array}$ \\
\hline $\begin{array}{l}\text { 5. Gaining benefits } \\
\text { on the perception of } \\
\text { consumers that milk } \\
\text { tea products are good } \\
\text { for their health. }\end{array}$ & 4.8 & $\begin{array}{c}\text { Strongly } \\
\text { Agree }\end{array}$ \\
\hline $\begin{array}{l}\text { Average weighted } \\
\text { mean } \\
\qquad(\mathrm{AWM})\end{array}$ & 3.56 & Agree \\
\hline
\end{tabular}

The potential opportunities Milk Tea Businesses always seize involves the installation of different utilities particularly the WI-FI connection for it is the most sought among their various customers. In addition, they continuously present their product offerings in a way that it creates impression that is good for the health and acquiring modern technology and equipment to speed up and ensure standard quality of their products and services.

The discovery of new resources for product development is an opportunity that Milk Tea Businesses sometimes take. It is because of the diversity of their current product offerings serves enough to satisfy the needs and demands of their different customers.

Table XIII: Threats

\begin{tabular}{|l|c|c|}
\hline \multicolumn{1}{|c|}{ Item Statements } & $\begin{array}{c}\text { Weighted } \\
\text { Mean } \\
(W M)\end{array}$ & $\begin{array}{c}\text { Descriptive } \\
\text { Value } \\
(D V)\end{array}$ \\
\hline $\begin{array}{l}\text { 1. The fast entry of } \\
\text { competitors in the } \\
\text { market. }\end{array}$ & 4.3 & $\begin{array}{c}\text { Strongly } \\
\text { Agree }\end{array}$ \\
\hline $\begin{array}{l}\text { 2. The seasonal } \\
\text { demand of the } \\
\text { product offered. }\end{array}$ & 4.3 & $\begin{array}{c}\text { Strongly } \\
\text { Agree }\end{array}$ \\
\hline
\end{tabular}

\begin{tabular}{|l|c|c|}
\hline \multicolumn{1}{|c|}{ Item Statements } & $\begin{array}{c}\text { Weighted } \\
\text { Mean } \\
(W M)\end{array}$ & $\begin{array}{c}\text { Descriptive } \\
\text { Value } \\
(D V)\end{array}$ \\
\hline $\begin{array}{l}\text { 3. The } \\
\text { competitiveness of } \\
\text { competitors. }\end{array}$ & 3.9 & Agree \\
\hline $\begin{array}{l}\text { 4. The negative } \\
\text { implication on the } \\
\text { reputation of the } \\
\text { business brought by } \\
\text { the milk tea scandal. }\end{array}$ & 3.1 & Sometimes \\
\hline $\begin{array}{l}\text { Average weighted } \\
\text { mean }\end{array}$ & $\mathbf{3 . 5 6}$ & Agree \\
\hline (AWM) & & \\
\hline
\end{tabular}

The greatest threat faces by the Milk Tea Businesses are the fast entry of competitors and the seasonal demand for product. The presence of a number of suppliers for a certain commodity resulted in a distribution or division of market share of each business. Although we are in a tropical country, but during rainy season, it causes a decrease of number of buyers due to change of climate.

The milk tea scandal sometimes affects the Milk Tea Businesses in Cabanatuan City but only it is something they consider as minor and manageable. It is because owners or the management of these businesses are confident on the standard operations, they practice that gain the trust of their customers.

4. Effects of harm done as experienced by the registered milk tea stores in Cabanatuan City caused by the 2015 Sampaloc, Manila Milk Tea Poisoning

Table XIV: Effects of Milk Tea Scandal

\begin{tabular}{|l|c|c|}
\hline \multicolumn{1}{|c|}{ Description } & Frequency & Rank \\
\hline $\begin{array}{l}\text { 1. Changing buying } \\
\text { habits of customers }\end{array}$ & 8 & 2 \\
\hline $\begin{array}{l}\text { 2. Sales volume } \\
\text { decreased }\end{array}$ & 8 & 2 \\
\hline $\begin{array}{l}\text { 3. Abating of } \\
\text { reputation of the } \\
\text { business }\end{array}$ & 7 & 4 \\
\hline $\begin{array}{l}\text { 4. Weakening of } \\
\text { competitors }\end{array}$ & 6 & 5 \\
\hline $\begin{array}{l}\text { 5. Changing of } \\
\text { government rulings } \\
\text { and others }\end{array}$ & & \\
\hline
\end{tabular}


The milk tea scandal causes doubts and worries to the buyers of this product that resulted to a change of buying habits of regular customers of milk tea stores which causes the decrease of sales generated by the businesses.

It only shows that the reputation or image perceived by customers greatly affects the business.

5. Strategies practice by Milk Tea Stores in handling problems

Table XV: Strategies in Handling Problems

\begin{tabular}{|l|c|c|}
\hline \multicolumn{1}{|c|}{ Description } & Frequency & Rank \\
\hline $\begin{array}{l}\text { 1. Systematic } \\
\text { problem approach } \\
\text { through improving } \\
\text { customer satisfaction } \\
\text { and efficiency }\end{array}$ & 7 & 1 \\
\hline $\begin{array}{l}\text { 2. Picking the right } \\
\text { issue }\end{array}$ & 6 & 2 \\
\hline $\begin{array}{l}\text { 3. Performing } \\
\text { problem solving } \\
\text { strategies road map }\end{array}$ & 5 & 3 \\
\hline $\begin{array}{l}\text { 4. Having multiple } \\
\text { back up plans }\end{array}$ & 4 & 0 \\
\hline $\begin{array}{l}\text { 5. Rely on } \\
\text { predictable events of } \\
\text { the situation }\end{array}$ & - & 4 \\
\hline
\end{tabular}

It is being said that, in business, customers must come first. That is the principle that guided the milk tea businesses in doing strategy on how they handle problems. Everything must always be focused on providing the best product and service offering to their buyers and even when something went wrong, it is easy for them to recover since it will just give way to improve more their operation.

Relying on the predictability of the situation is something that milk tea businesses didn't practice because for them results or outcomes of this strategy will mostly be unpredictable which is very risky.

\section{CONCLUSIONS}

After the analysis of gathered data, the researcher the come up with the following conclusions:

Milk Tea Businesses is a new industry emerging in Cabanatuan City. This type of business is easy to put up and easy to manage, with minimal capital and employee's requirement to operate. But the popularity and type of services it offers to various customers, like a good place to hang out and to relax while having luscious refreshment and snacks make this type of business viable.

Strategies in managing this type of business is necessary, particularly in maintaining the quality standard of product and services for this is how they can obtain the loyalty and trust of their customers. That is why businesses of this type seldom use advertising and promotion as a means to promote their business. A word of mouth is enough to gain additional customers. Furthermore, a fixed pricing policy is mostly practice by these businesses where a desirable mark-up is already included on the selling price acceptable to their buyers.

The main strength of this type of business is in its location as well as the superb taste, branded services offered by the milk tea stores, and the efficiency and effectiveness of employees. All those strengths can be achieved through proper planning. In terms of the weaknesses, rarely did the milk tea stores encountered problems in dealing with their weak points. An indication that the businesses are well manage and that it continuously meet the organization's objectives while continuously satisfying their customers' needs and wants. Because of the perception of the general public that milk tea products are healthy or good for the body, considering that a number of individual now days are health conscious, milk tea businesses take that advantage and package their products in a healthy way. The leading pressure among the threats in this type of business is the fast entry of competitors that leads to further distribution and decrease of market share of each milk tea businesses.

The milk tea scandal causes doubts and worries to the buyers of this product that resulted to a change of buying habits of regular customers of milk tea stores which causes the decrease of sales generated by the businesses. This shows that the reputation or image perceived by customers greatly affects the business.

The principle of, customers must come first guided the milk tea businesses in doing strategy on how they handle problems. Everything they do always focus on providing the best product and service offering to their buyers. Relying on the predictability of the situation is something that milk tea businesses didn't practice because for them results or outcomes of this strategy is most likely unpredictable and very risky.

\section{RECOMMENDATIONS}

After the analysis of the study and making conclusions, the following recommendations were made: 
1. The Milk Tea Business must impose and maintain at all times the standards in processing their product and servicing their customers. They should always be reminded that the reputation or image of the business has great influence to the successful operation of the business.

2. Provide continuous training and other personnel development programs that could motivate the spirit of the employees at all times for them to perform well.

3. Giving sales promotion like discount card, loyalty card and taking advantage more of social media could further increase the sales and number of the customers.

4. Developing or discovering new product offerings can give additional competitiveness to the business, especially if it is something original and can only be found or experienced in their store.

\section{ACKNOWLEDGMENT}

The researcher would like to thank NEUST Administration, the CMBT Family headed by Dean Marilou P. Pascual, Ph.D, and especial mention goes to Dr. Felipe Balaria, Dr. Gemma Santos and Dr. Ma. Germina Santos for all the help and support that you gave her in the completion of this report.

\section{REFERENCES}

[1] www.nutraingredients.com/reseaech/milk-in-teamay-hamper/heart-haelth/healthbenefits

[2] www.dimnl.com/lifestyle/philippines-milk-tea$\underline{\text { business }}$

[3] www.ncbl.nlm.nih.gov/pmc/article/PMC 3013591

[4] www.rapper.com/nation/02858-milk-tea-poisiningoxalic-acid

[5] https://www.hongkong.edu/ted/ milktea.htm

[6] https://scholar.lib.vt.edu/theses/available/ etd10302008120535/unrestricted/ LD5655.V855_1979.K52.pdf

[7] https://www.ijsse.org/articles/ijsse_vl_i9_ 418_430.pdf

[8] https://www.nesc.wvu.edu/subpages/septic_defined.c fm 